\title{
Планински региони и њихов културноантрополошки семиотички пејсаж
}

\section{Mountain Areas and Their Cultural Anthropological Semiotic Landscapes}

Мартин Хенцелман

(Грајфсвалд, Немачка)

\section{Апстракт:}

Овај чланак испитује културноантрополошку улогу планина и њихову везу са језичком теоријом семиотичког пејсажа (скраћено СП). Прво су представљени главни аспекти културне антропологије и њене европске оријентације, за чије су битне налазе заслужни француски антрополози. Иако они у својим истраживањима укључују пејзажне појаве, често се фокусирају на урбане структуре. Стога се овај рад ठави проблематиком какву улогу ретко насељена подручја, попут планина, имају за културноантрополошка питања. Ово је такође повезано са питањем какву семиотичку улогу има језичка регулација у специфичној просторној структури. Испитује се комбинација различитих фактора који могу научно објаснити културноантрополошки значај појединих планинских пејзажа кроз циљано укључивање СП. На овај начин се у фокус ставља интеракција измећу језика и његовог окружења. Користећи одабране примере, такође је приказано које функције поједина места обављају овом интеракцијом језика и места, и која је то специфична сврха.

\section{Кључне речи:}

културна антропологија; семиотички пејсаж; планине; језичка структура простора; интеракција језика и околине 


\section{Abstract:}

This paper highlights the cultural anthropological significance of mountain areas in the context of the linguistic theory of semiotic landscapes. It introduces some key points of cultural anthropology and its European tradition, the main insights of which are owed to French anthropologists. Although these anthropologists include some rural related phenomena in their work, they predominantly focus on urban structures when speaking about landscape. Therefore, the present paper addresses the question of the role of uninhabited areas, such as mountains, and their significance for cultural anthropological research. This is linked to the semiotic ground of linguistic relevance in space. Structures are identified, which can explain the cultural anthropological meaning of certain mountain areas by the inclusion of semiotic landscapes. Thus, the interaction of language and environment is brought into focus. Selected examples are used to illustrate what function places perform through the interplay of language and space.

\section{Key words:}

cultural anthropology; semiotic landscapes; mountain areas; space and structure; language in space

\section{1. Културна антропологија}

Културна антропологија бави се питањем који културни феномени играју улогу у људском животу и како се могу анализирати. Француски тренд у антропологији овде игра кључну улогу, чији је развој описан у уводном есеју Габриеле Ментгес ${ }^{1}$ на следећи начин: педесетих година прошлог века из САД се вратио Клод Леви-Страус (франц. Claude Lévi-Strauss) и увео концептуалнотеоријски апарат антропологије, и користио га првенствено у смислу социјалне антропологије. То су касније преузели и даље развили аутори Бонт (франц. Bonte) и Изар (франц. Izard), јер у својим истраживањима говоре о синтези етнографије као добијање информација, етнологије као анализа добијених података и антропологије која има за циљ произвести нова знања кроз поређења и концептуализације. У сваком случају, циљ студија је проширити наше знање о човечанству уопште. Француски етнолог

1 MENTGES, G.: Für eine Kulturanthropologie des Textilen. Einige Überlegungen. In: MENTGES, G. (Hrsg., unter Mitarbeit von Nina Schack und Heike Jenß): Kulturanthropologie des Textilen. Sonderband. Textil - Körper - Mode. Dortmunder Reihe zu kulturanthropologischen Studien des Textils. Berlin: Ebersbach \& Simon, 2005, стр. 11-12. 
и антрополог Марк Оже (Marc Augé) посвећује једну од својих студија питању урбаних структура и њихове антрополошке важности ${ }^{2}$. Велики градови имају традицију у контексту антрополошких студија, посебно јер нуде широк спектар могућности за друштвену и просторну интеракцију. И на крају, такође су Французи дефинисали поделу између појма «место» и «простор», нарочито Мишел де Серто (франц. Michel de Certeau). Сходно томе, «места» доприносе извесном очувању догађаја јер су тренутна сазвежђа непокретних тачака. То значи да за њега места представљају архитектонске или природне структуре које су непроменљиво постављене. За њега су, с друге стране, «простори» живахне и стално обнављајуће структуре у којима се могу уочити правци, брзине и варијације. Под овим он подразумева подручја у којима се живот одвија, на пример, улица у граду ${ }^{3}$. За ову студију стога можемо претпоставити да су «простори» првенствено стазе за посетиоце националних паркова, док се одређене фиксне тачке, попут путоказа, могу класификовати као «места». У позадини културне антропологије, мећутим, морамо узети у обзир и визуелне и језичке појаве у нашем случају, које се могу препознати у одрећеним тачкама и које преузимају нове студије. Претпоставља се да визуализације могу помоћи у успостављању симболичне заштитне функције и јачању сигурности културних пејзажа ${ }^{4}$. У језичком смислу, ови предели се често описују као системи знакова који помажу у објашњењу целине кохерентне структуре ${ }^{5}$. За ово се сада мора успоставити и веза са семиотичком пејсажом.

\section{2. Значај семиотичког пејсажа}

У контексту антрополошких питања, не треба потцењивати значај језика и његову интеграцију у јавни простор. Ово је експлицитно циљ теорије семиотичког пејсажа (СП), који се првенствено односи на истраживање језичке структуре места или простора и њихово повезивање са визуелним утисцима из окружења. На овај начин се анализирају интеракције између језика, простора и знакова како би се извели закључци о феноменима својственим култури.

2 WEISS, S.: „Orte und Nicht-Orte“. Kulturanthropologische Anmerkungen zu Marc Augé. Mainzer kleine Schriften zur Volkskultur, 14. Mainz: Gesellschaft für Volkskunde in Rheinland-Pfalz e.V., 2005, стр. 9-10.

3 Ibidem, стр. 20-21.

4 SALAŠOVÁ, A.: Vizuálne hodnotenie krajiny v kontexte ochrany krajinného rázu. Životné prostredie, 3, 2020.

5 LINDSTROMM, K. - KULL, K. - PALANG, H.: Landscape Semiotics: Contribution to Culture Theory. In: LANG, V. - KULL, K. (eds.): Estonian Approaches to Culture Theory. Approaches to Culture Theory, 4. Tartu: University of Tartu Press, 2014, стр. 113-114. 
Посебну улогу у томе има студија Адама Јаворског и Криспина Турлоа ${ }^{6}$, који говоре о томе да писани дискурс, који је присутан и при изношењу информација, увек има интеракцију с другим дискурзивним модалитетима. Из тог разлога се не истражује првенствено структура одрећених простора квантитативно, као што је случај у лингвистичком смеру језичког пејсажа (енгл. Linguistic Landscapes), него се покушава што прецизније описати утиске који се могу открити кроз конкретну интеракцију писања и јавног простора. У том контексту, недавно су се појавиле бројне студије које се баве ситуацијом у урбаним срединама и фокусирају се на вишејезичне структуре. Ово се може повезати са чињеницом да урбани простори пружају мноштво јавних натписа, на пример у прометним трговачким улицама, урбаним подручјима са високим уделом миграната (истраживала је Гонсалвес у Њујорку) ${ }^{7}$ или туристичким центрима. Због тога је релативно лако суочити се са СП-ом у великим градовима и прикупити материјал који се може опсежно користити као основа за документацију. Студије које се ठаве руралним подручјима и њиховим језички уређеним структурама су много ређе (нпр. Мел са фокусом руралне структуре у Француској) ${ }^{8}$, јер у њима наилазимо много мању количину материјала. Осим тога, тачке на којима се може открити писање често су удаљеније него у великим градовима, где једна продавница стоји поред друге и користи било који облик и слова. Другим речима, ово такође значи да је квантитативно оријентисана студија у руралним подручјима мање значајна него у великим градовима, тако да морамо да стављамо питање у правцу које специфичне функције могу преузети поједини знакови. Ипак, ретко насељене просторне структуре су ређе предмет лингвистичких истраживања, као нпр. Нет ${ }^{9}$, јер је у сличним подручјама текстуални материјал који се налази у јавном простору много ређи. Из тог разлога, циљ ове студије је покушати испитати одређене структуре у планинским регијама које су у основи привремено доступне, а истовремено једва стално настањене. Стога морамо претпоставити да се натписи у јавном простору морају посебно бавити културноантрополошким аспектима и позвати семиотичке мреже како

6 JAWORSKI, A. - THURLOW, C.: Introducing Semiotic Landscapes. In: JAWORSKI, A. - THURLOW, C. (eds.): Semiotic Landscapes, Language, Image and Space. London - New York: Continuum, 2010, стр. 1-40.

7 GONÇALVES, K.: Semiotic Landscapes and Discourses of Place within a Portuguese-Speaking Neighborhood. In: Interdisciplinary Journal of Portuguese Diaspora Studies, 1, 2012.

8 MØHL, P.: Village Voices: Coexistence and Communication in a Rural Community in Central France. Copenhagen: Museum Tusculanum Press, 1997.

9 NÖTH, W.: Ecosemiotics and the Semiotics of Nature. In: Sign Systems Studies, 29, 1, 2001. 
би се посетиоцима пружили аутентични подаци о њиховом боравишту са културноантрополошке тачке гледишта.

\section{3. Планине као предмет лингвокултуролошког истраживања}

Планине су занимљив предмет за лингвокултуролошка истраживања из различитих разлога. С једне стране, постоје веома ретко насељена подручја која се углавном посећују у туристичке или научне сврхе. Унутар постоје занимљива флора и фауна, реке, планине и друге природне појаве које се посећују. С друге стране, ова места су опремљена културноантрополошким објектима који испуњавају одређене симболичне, мистичне, традиционалне, географске или туристичке функције, које се такође могу анализирати из семиотичке перспективе. Ови објекти су обично означени знаковима или таблама који служе за боље разумевање одговарајућих локација и пружају важне информације посетиоцу. У наставку ћемо погледати примере из националних паркова на различитим словенским језичким подручјима и ставити њихов СП у директну везу са културноантрополошком релевантношћу места или простора у њиховом локалном контексту ${ }^{10}$

\section{1. Планине као место одговорности и савесности}

Важан људски квалитет је бити одговоран и савестан. То омогућава хармоничан међусобни контакт, подједнако је добро за међусобно опхођење и повећава квалитет живота. У неким случајевима, ова хармонија преноси се на присуство људи у резерватима природе у којима се туриста подсећа да се понаша савесно и да увек пази на животну средину. Ово се може илустровати следећим примерима (стр. 34).

На илустрацији № 1 видимо словеначки натпис «С̌e si planinec pravi, smeti v nahrbtnik spravi» («Ако си истински планинар, онда смеће стављај у ранац») на планинском зиду у Националном парку «Триглав» у северозападној Словенији. Парк је веома популарна планинарска зона са изузетним природним појавама, издашним стазама за планинарење и пењање, и може се описати као јединствена туристичка дестинација. Због своје популарности, национални парк привлачи бројне посетиоце, нарочито лети. Нажалост, то такође значи да се понекад отпад налази поред пута. Ово не само да загађује животну средину, већ оставља и непријатан визуелни утисак. Из тог разлога, ознака апелује на све планинаре да увек буду свесни своје одговорности према природи и да уклоне сопствени отпад у своју торбу. Поред овог директног захтева, ручно

10 Све фотографије овог рада су дело аутора чланка. 


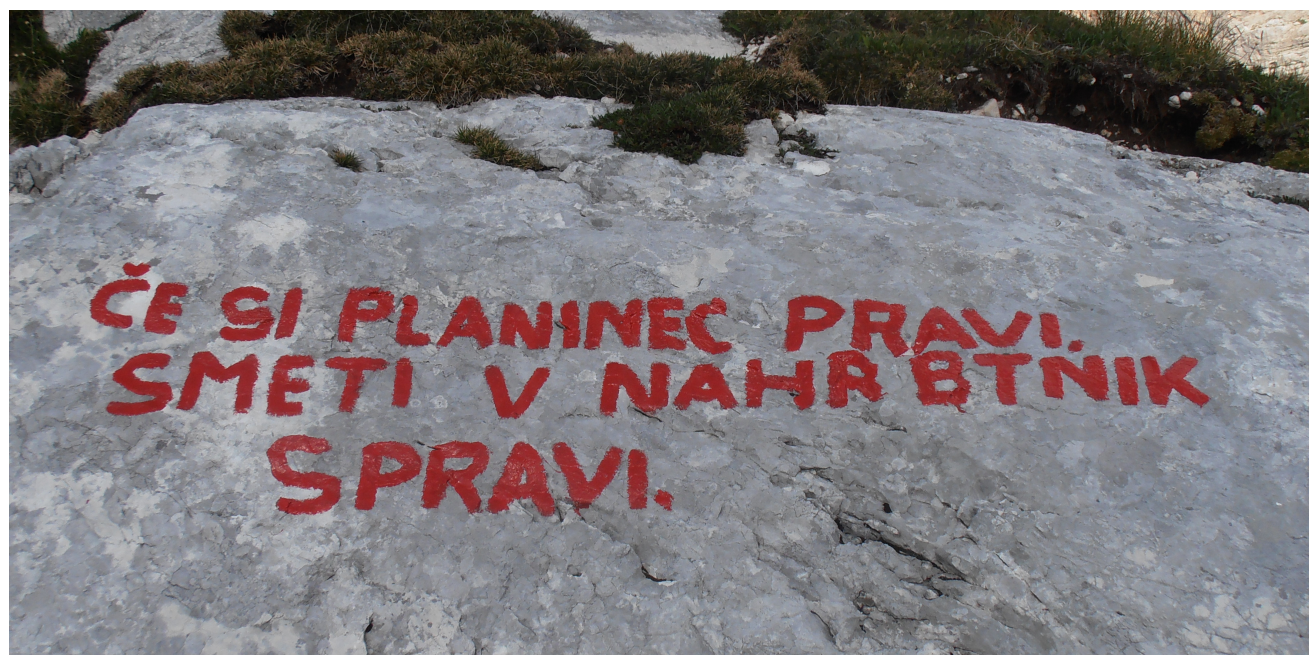

Илустращија № 1: Ручни натпис у Нащионалном парку «Триглав» (Словенија)

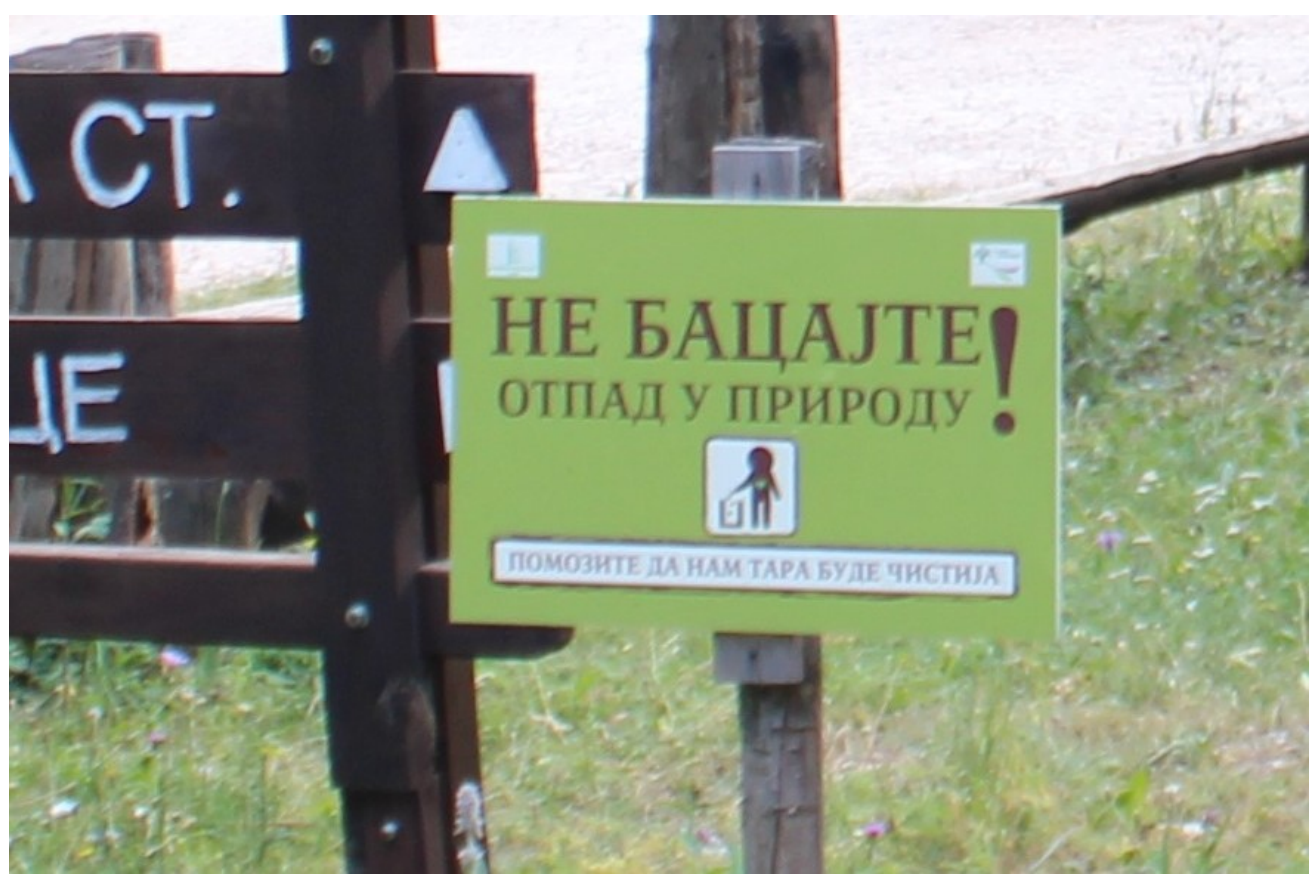

Илустращија № 2: Званични натпис у Нащионалном парку «Тара» (Србија) 
написан натпис подразумева да посетилац треба да буде еколошки свестан када одлази у природу. Дакле, постоји директна корелација измећу савесности и заштите животне средине. Истовремено, то значи да се од посетиоца очекује основни морални став који се даје избегавањем смећа. Посебна карактеристика овде је римована изрека која се може лако запамтити и тако додатно подстиче планинара да испуни захтев.

Илустрација № 2 је званично постављени знак на коме читамо «Не бацајте отпад у природу!». Налази се у Националном парку «Тара» у западној Србији. Овај парк је такође веома популаран, посебно код породица које путују са децом и праве мање захтевне излете. Пошто је то веома сјајно излетиште које посећују различите генерације, за очекивати је да се отпад не може избећи током посете. Први део ознаке («Не бацајте») написан је много већим делом од осталог. Овде се ради о директном захтеву који посетиоцу јасно саопштава од чега се мора уздржати. Поред тога, постоји додатак који се налази испод овог захтева, тј. «отпад у природу», и ускличник као карактеристика хитности. Ово је допуњено објашњењем да гост сам себи помаже тиме што не баца смеће у природу и даје директан допринос очувању природе. Такође је изражено да се смеће мора одлагати у за то предвиђене канте, које су бројне на лицу места. То је јасно из пиктограма испод текста. Ово апелује на личну одговорност и бригу за природу како би се гарантовала чистоћа парка и тиме омогућило свим осталим гостима угодан боравак.

Чињеница да смо пронашли ове податке лежи у томе да не можемо очекивати да се сви посетиоци придржавају закона да не бацају своје смеће у природу. Значење текстова се стога мора пре свега тумачити прагматично и сврсисходно, па је важно све посетиоце на одговарајући начин упутити на то. Осим самог натписа, овај циљ је подвучен употребом две боје. На првој слици текст је обележен црвеном бојом. Црвена је боја опреза, упозорења и забране. Често се може наћи у природним појавама, на пример као боја неког цвета или бубе, али и као боја ватре, а тиме и топлине и опасности у исто време ${ }^{11}$. Црвена најбоље привлачи пажњу и уједно опомиње. На илустрацији № 2 налазимо смеђи натпис на зеленој подлози. Обе боје су посебно важне у природи, јер смеђа подсећа на стабла, гранчице, лишће и земљу, док је зелена најважнија боја у природи, она симболизује лист, траву, биље, паркове и маховину ${ }^{12}$.

11 BARTEL, S.: Farben im Webdesign. Symbolik, Farbpsychologie, Gestaltung. 112 Abbildungen. Berlin-Heidelberg: Springer, 2003, стр. 48-55; DOBROVOL'SKIJ, D. - PIIRAINEN, E.: Symbole in Sprache und Kultur. Studien zur Phraseologie aus kultursemiotischer Perspektive. Studien zur Phraseologie und Parömiologie, 8. Bochum: Universitätsverlag Dr. N. Brockmeyer, 2002, стр. 266.

12 BARTEL, S.: Farben im Webdesign. Symbolik, Farbpsychologie, Gestaltung. 112 Abbildungen. Berlin-Heidelberg: Springer, 2003, стр. 65-71; DOBROVOL'SKIJ, D. - PIIRAINEN, E.: Symbole in Sprache 
Тако се у суштини користе боје које посетиоца најјасније подсећају тамо где се тренутно налази. У оба случаја можемо јасно видети образовне мере које привлаче савест туриста и упућују га да се суздржи од наношења штете животној средини. Од туристе се очекује да добровољно пристане да се придржава ових правила, јер се не спомињу санкције за непоштовање. Тако се у овим случајевима ради о морализацији семиотичког пејзажа планина.

\section{2. Планине као место сећања}

Постоје планине које су постале симболична места када су се на њих попеле познате личности, када су се одређени догађаји одиграли на лицу места или када имају висок естетски карактер. Погледаћемо и два примера овога (стр. 37).

Илустрација № 3 приказује таблу на врху «Кривањ», који са својих 2494 метара нуди одличну панораму над Татрама. Осим тога, због свог специфичног облика и особености у историји Словачке, сама планина је ушла у својеврсни мит, са којим се вежу бројне легенде, али и најважније личности из времена националног препорода XIX. века. Плоча коју је направила «Матица словачка» подсећа на успон Људовита Штура (слов. L’udovít Štúr), једног од централних оснивача савременог словачког књижевног језика, и његових сапутника. Тако се изазива симбиоза између изузетног места и значајних личности које су нераскидиво повезане са читавом земљом, њеним језиком и пре свега са њеном историјом. Стога је то спомен-обележје од националног значаја.

На илустрацији № 4 видимо плочу која је причвршћена за Аљажев столп на врху Триглава, на 2864 метра највише планине у Словенији. Планинари могу пронаћи склониште у овом малом торњу на кратко, на пример током невремена. Триглав је централни национални мотив у словеначком контексту, који је такође повезан са бројним личним и митолошким догађајима ${ }^{13}$. Планина је најважнији природни симбол у држави и чак краси национални грб, што већ указује на њену изузетност. Планински врх такође дефинише национални идентитет, због чега се спомен-плоча односи и на догађај од националног значаја: Крајем 1944. партизани који су се борили против италијанских и немачких јединица су се попели на врх планине «Триглав», и стога је овде одбрана отаџбине симболично повезана са конкретном местом.

И на илустрацијама № 3 и № 4 знак подсећа на плакету или медаљу која личи на награду. У оба случаја имамо посла са једнојезичним представама које су

und Kultur. Studien zur Phraseologie aus kultursemiotischer Perspektive. Studien zur Phraseologie und Parömiologie, 8. Bochum: Universitätsverlag Dr. N. Brockmeyer, 2002, стр. 275-283.

13 HROBAT VIRLOGET, K.: Deva, Baba in Triglav v mitskem izročilu in pokrajini. In: Sodobnost, jan.-feb., 78, 1/2, 2014, стр. 102-103. 


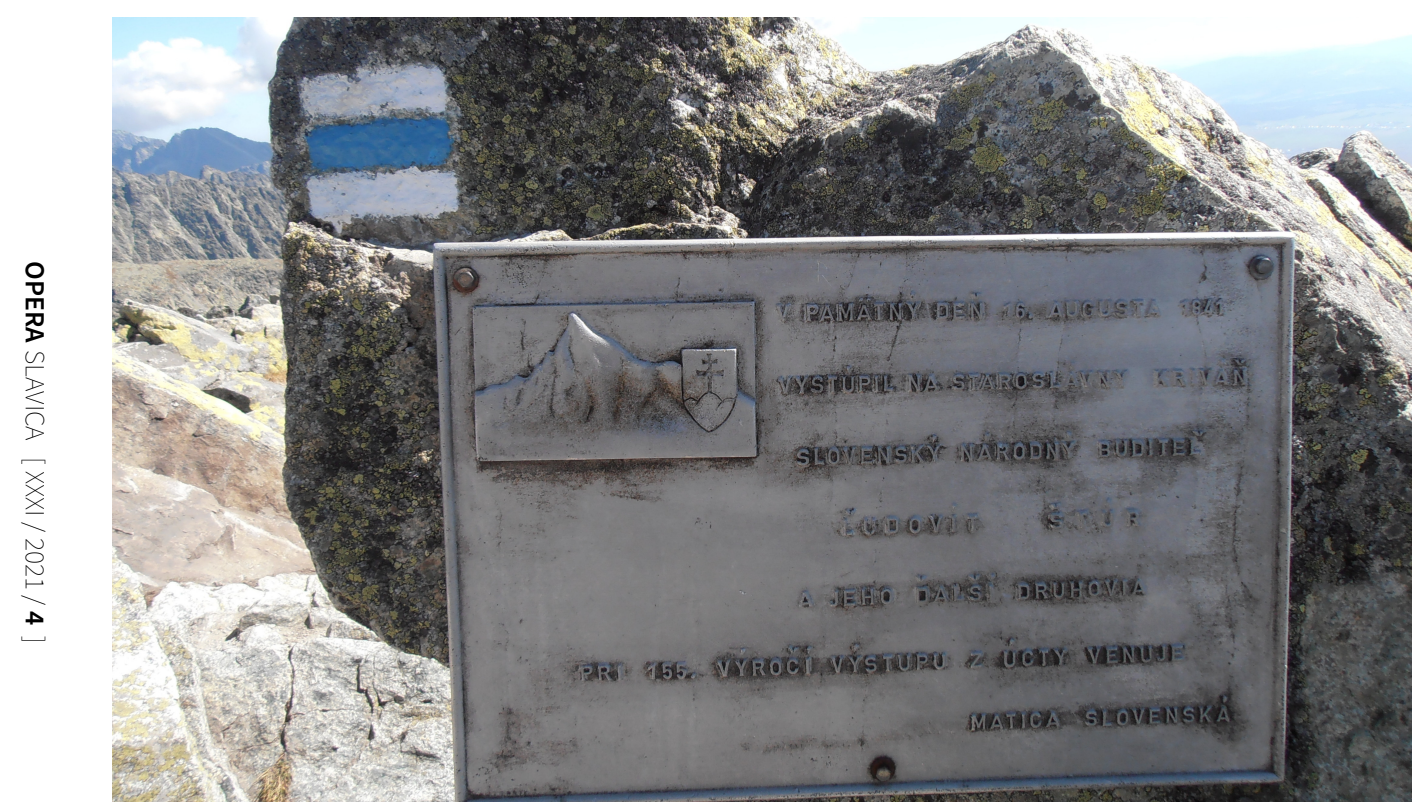

Илустрација № 3: Табла на врху планине «Кривањ» (2494 м) у Националном парку «Татра» (Словачка)

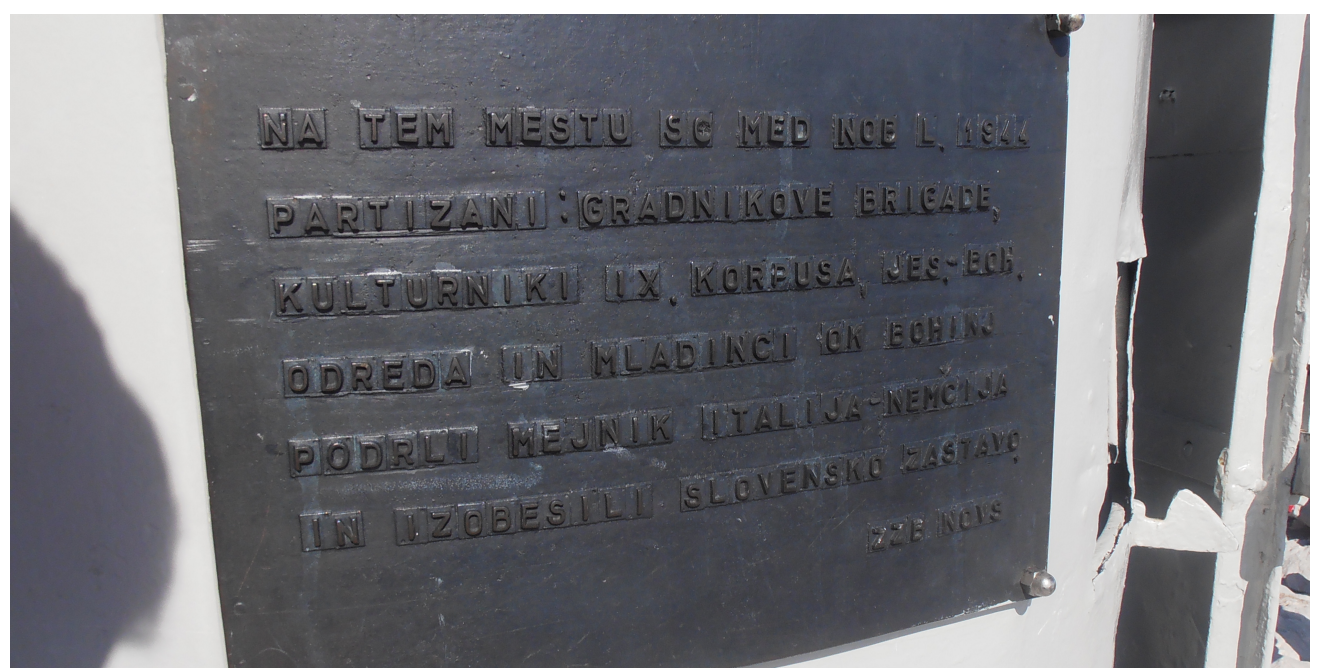

Илустращија № 4: Табла на Альажевом столпу на врху планине «Триглав» (2864 м) у Националном парку «Триглав»

(Словенија) 
осмишљене за национални контекст (у коме су лако разумљиве). Из семиотичке перспективе, то је визуелна историзација места сећања, која има за циљ да подсети посетиоца на важне догађаје и личности. Ово такође симболизују пробушена слова, која као пример могу представљати отисак у сећању нације. Може се видети да су структуре боја овде намерно изостављене и да се користи само природни материјал у својим нијансама сиве, који се исто стапа са утисцима пејзажа. Спомен-плоча тако делује као целина, у којој се такође може тражити аналогија јединства нације. Тако се на апстрактном нивоу компоненте простора, времена и радње спајају у велику целину, које су згуснуте на симболичком месту.

\section{3. Планине као објекат коришћења простора}

Планине нису само место где сећања на сопствену историју могу бити семиотична, већ и омогућавају мећународне сусрете. Бројне националне паркове посећују људи из различитих земаља. Ово не само да повећава мећународни значај локације, већ захтева и вишејезично означавање на одрећеним тачкама и добро осмишљену стратегију коришћења простора, што се види на следећим сликама (стр. 39).

На илустрацији № 5 можемо видети знак из Националног парка «Крконоше», који је причвршћен испод Снежке, која је са 1603 метара највиша планина у Чешкој Републици. Пошто се налази у непосредној близини границе са Републиком Пољском, генерално се може очекивати путнички саобраћај из обеју држава. С обзиром да се месту може приступити само пешице, натпис указује на важност коришћења само означених стаза и стога се може сматрати обавезујућим прописом. Захтев је прво упућен на чешком, а затим на енглеском и немачком (али не на пољском) језику и очигледно има за циљ да помогне посетиоцима да се усмере на прави пут. Сходно томе, није пожељно кретање изван ознака. Стога је то експлицитни захтев и имплицитна забрана.

Илустрација № 6 приказује знак у Националном парку «Татра» на словачкој страни. Налази се на рубу добро посећене пешачке стазе, на којој се може прошетати до виших врхова около Кривања. Пошто је регион близу границе који посећују и људи из различитих земаља, централне информације приказане су на неколико језика, тј. прво на државном словачком, затим на немачком, а потом на енглеском језику. Обавештење је о томе када је рута затворена (годишње од 1. новембра до 15. јуна), што туристи могу користити као оријентацију за посету. Иако не видимо оправдање за информације дате на илустрацији №5, тачан разлог је дат овде на илустрацији №6. Разлог затворене стазе на одређено време одговара заштити околине. Стога се 


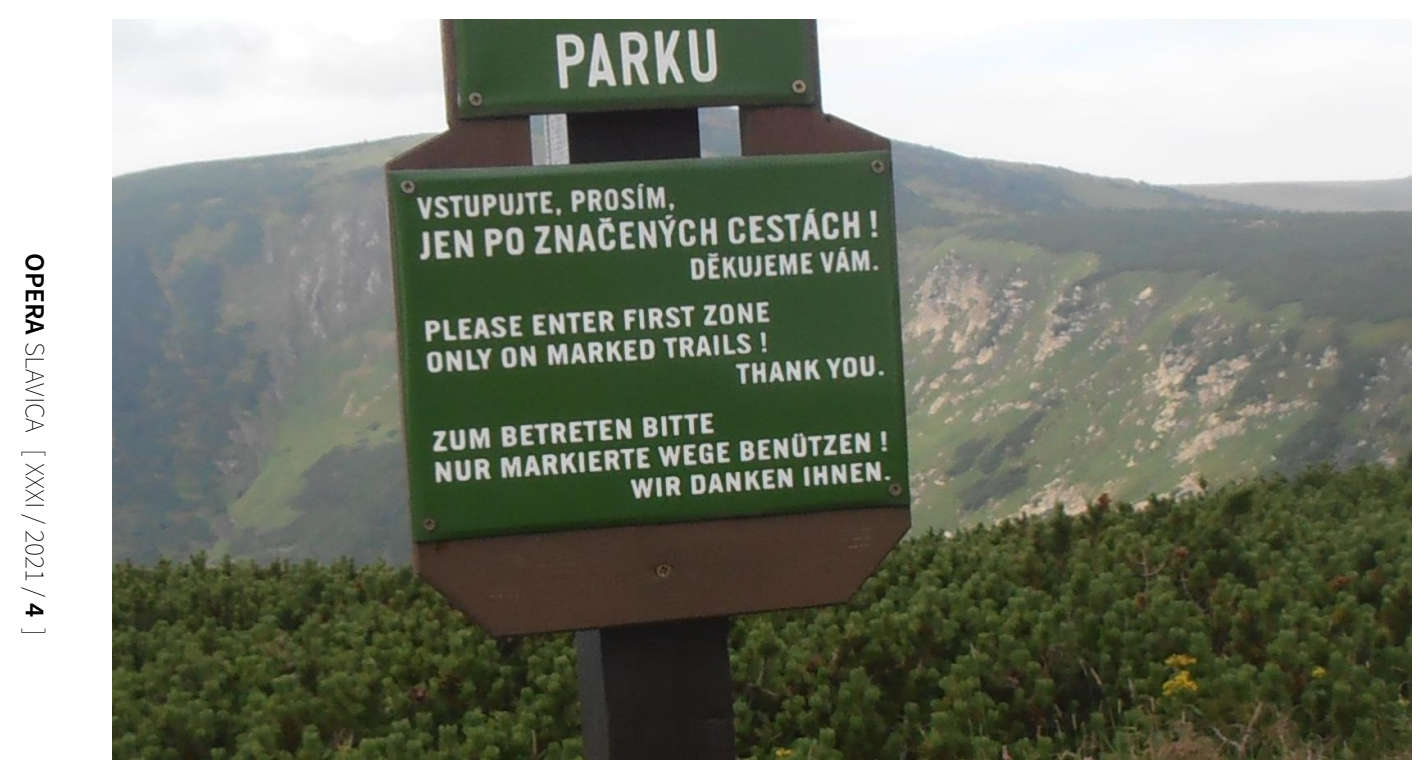

Илустрација № 5: Натпис испод планине «Снежка» (1603 м) y Националном парку «Крконоше» (Чешка)

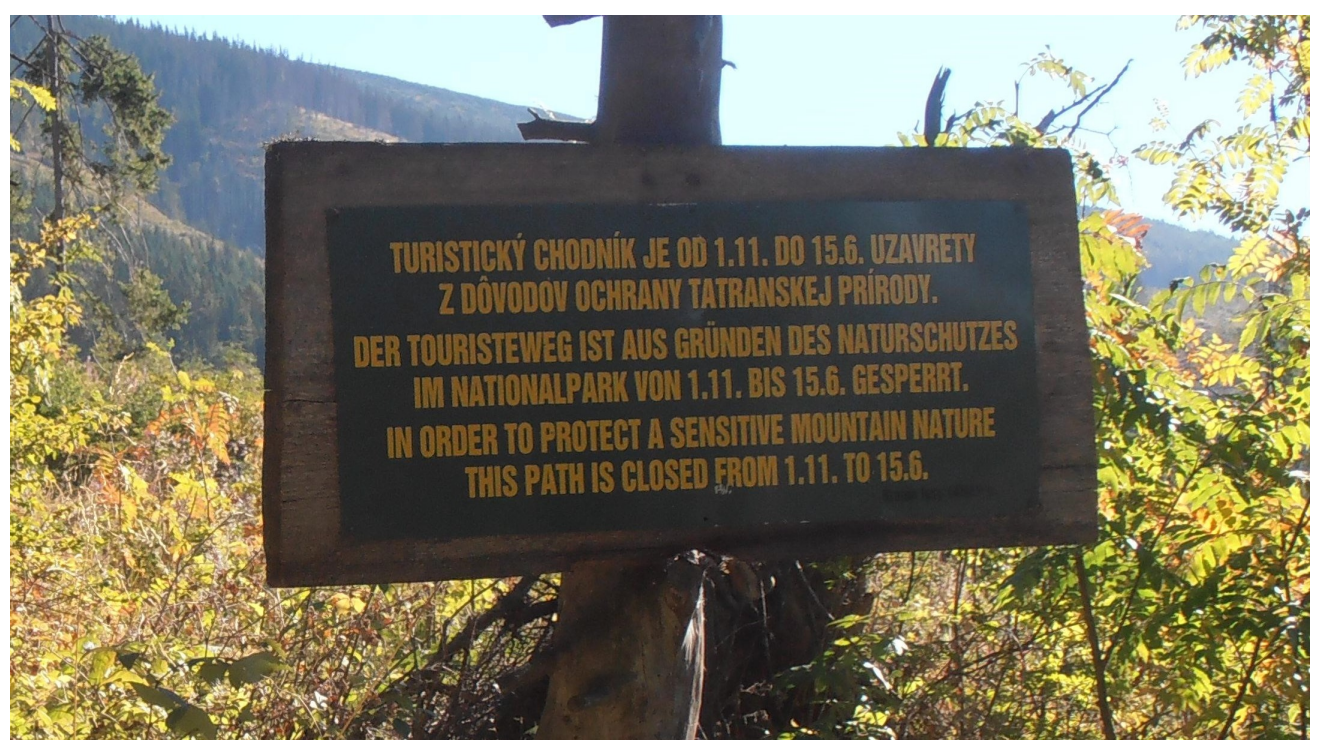

Илустращија № 6: Натпис на путу на врх «Кривањ» y Националном парку «Татра» (Словачка) 
експлицитно бавимо оправданом еколошком и стратешком мером која се саопштава посетиоцима, али која подразумева и забрану улаза. Дакле, не ради се о специфичној наменској употреби деонице као на илустрацији № 5, већ о потпуном затварању целе руте у поменутом периоду.

Ако прелазимо национални парк «Татра» са словачке стране на пољску, наићи ћемо на вишејезичне важне информације (стр. 41). Ово је приказано на илустрацији № 7, која упозорава планинаре да буду опрезни и на пољском и на енглеском језику. Туристичка стаза која води преко превоја «Заврат» (то је планински превој на 2159 метара) до планине «Кожи Вјерх» (2291 м) може се користити само у једном смеру. Овај знак хитно позива на опрез, али делимично само на пољском, што је јасно препознатљиво по упадљивом наслову знатно већим словима «Uwaga!» («Опрез!») (стр. 41). Туристи би стога требало добро да испланирају своју руту и изричито им се саветује у којем смеру се могу кретати ако желе прећи одређену удаљеност. Имплицитно, то истовремено значи да је забрањено и опасно кршити овај пропис. Другим речима, главна сврха ове ознаке је да осигура безбедност посетилаца.

Илустрација № 8 је из Националног парка «Рила» у југозападној Бугарској, који је дом веома познатих природних униката, попут Рилских језера. Овде постоје и понекад неосигуране стазе, од којих се неке тешко виде на неравном терену. Стога постоје ознаке које траже од посетилаца да крену само одговарајућом рутом. У принципу је упоредиво са илустрацијом № 5, али је приметно да је написана само на бугарском језику. То значи да централне информације у ствари нису доступне страним посетиоцима.

Важност и истовремено заштитна функција природног подручја појачавају се приказивањем његове просторне структуре и наменом коришћења рута. На знаковима се посетиоци појачано позивају да се придржавају ових означених стаза и да се понашају у складу са правилима. Као резултат тога, тежи се различитим циљевима, који првенствено служе заштити животне средине, али и личној безбедности и на тај начин спречавају ризике. Натписи доприносе специфичној комуникацији о могућој употреби природне инфраструктуре, истовремено указују на пут и у неким случајевима су усмерени према међународним туристима. Они имају функцију структурирања йростора. Ово је још више случај када се тражи вишејезична сигнализација, јер то подвлачи значај одговарајуће структуре.

\section{4. Закључци}

На основу теоријских студија о културној антропологији које смо споменули на почетку, можемо претпоставити да места, односно статичке компоненте, 


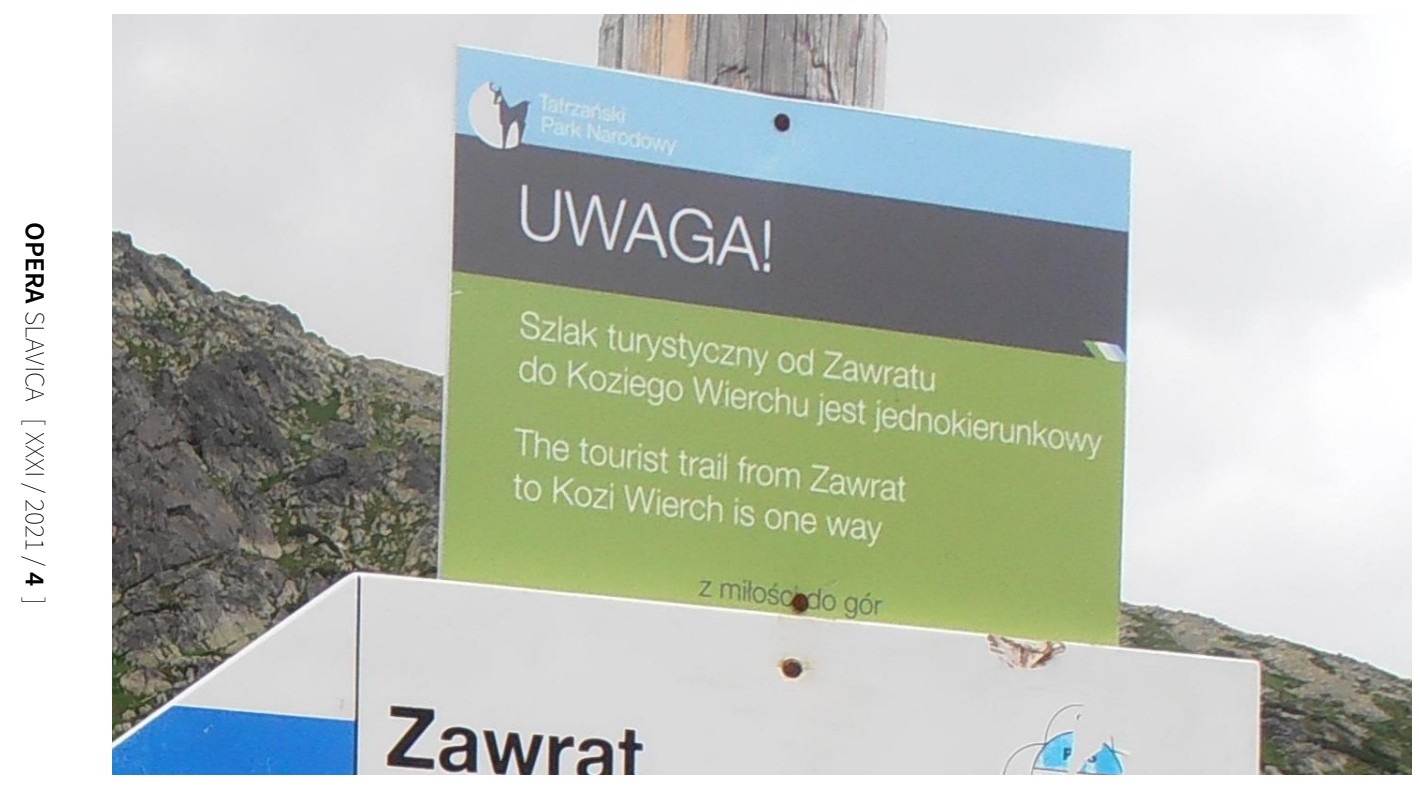

Илустрација № 7: Натпис у Националном парку «Татра» (Польска)

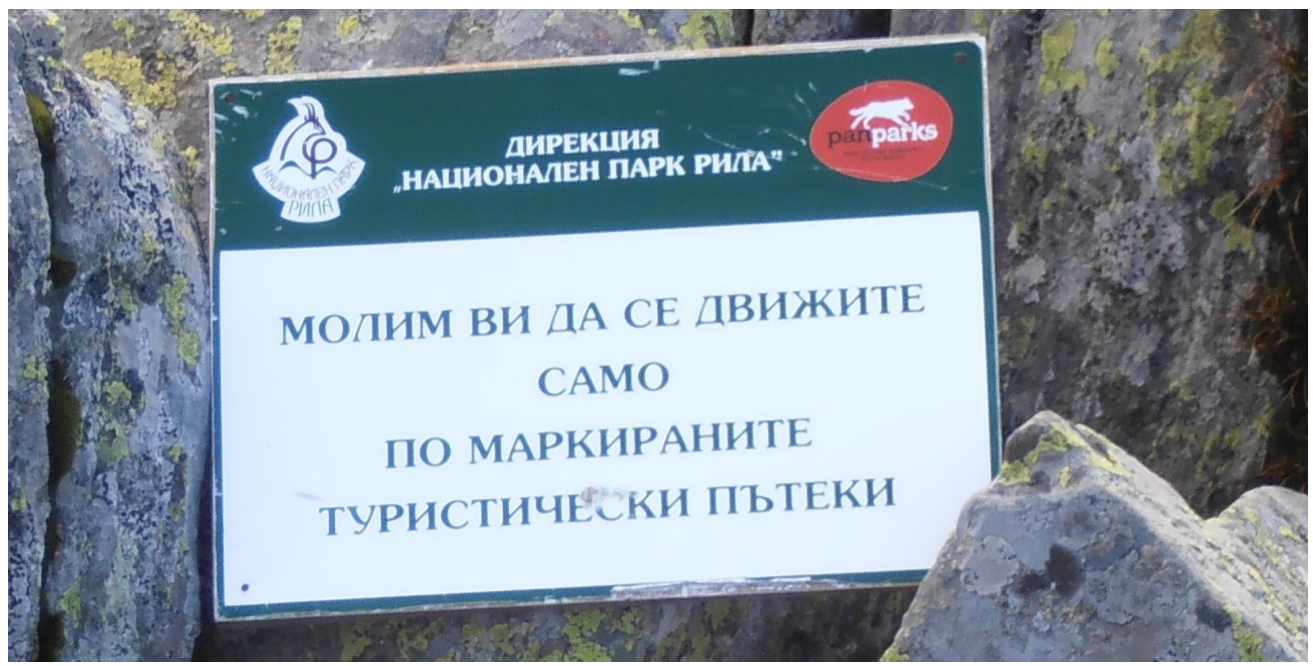

Илустращија № 8: Натпис у Нащионалном парку «Рила» (Бугарска) 
играју важну улогу у планинама. Служе, на пример, за морализацију (поглавље 3.1.), историзацију (поглавље 3.2.) или йросторно структуриране (поглавље 3.3.). Они су корисни географским (у ужем смислу динамичким и статичним), историјским, културним и језичким компонентама које, комбиноване, омогућавају локалну спецификацију. Помоћна средства као што су илустрације, варијације боја, величине слова, вишејезични натписи или одређена локација знака могу се користити за појачавање појединачних компонената. Изнад свега, у овом контексту треба посебно нагласити интеракцију између визуелних утисака из окружења и употребе писма, јер као што видимо, није довољно ограничити се на појединачне слике или симболе као што су пиктограми како би се постигли жељени ефекти код посетилаца. Напротив, игра централну улогу у томе како се језик може што конкретније користити циљано како би се са само неколико речи позвао на важне и широко примењиве чињенице. За надати се да ће се будућа истраживања свеобухватно бавити овом темом и истражити структуре важних словенских културних пејзажа у позадини теорије СП.

\section{Литература:}

BARTEL, S.: Farben im Webdesign. Symbolik, Farbpsychologie, Gestaltung. 112 Abbildungen. Berlin-Heidelberg: Springer, 2003.

DOBROVOL'SKIJ, D. - PIIRAINEN, E.: Symbole in Sprache und Kultur. Studien zur Phraseologie aus kultursemiotischer Perspektive. Studien zur Phraseologie und Parömiologie, 8. Bochum: Universitätsverlag Dr. N. Brockmeyer, 2002.

GONÇALVES, K.: Semiotic Landscapes and Discourses of Place within a Portuguese-Speaking Neighborhood. In: Interdisciplinary Journal of Portuguese Diaspora Studies, 1, 2012, s. 71-99.

HROBAT VIRLOGET, K.: Deva, Baba in Triglav v mitskem izročilu in pokrajini. In: Sodobnost, jan.-feb., 78, 1/2, 2014, s. 98-117.

JAWORSKI, A. - THURLOW, C.: Introducing Semiotic Landscapes. In: JAWORSKI, A. THURLOW, C. (eds.): Semiotic Landscapes, Language, Image and Space. London New York: Continuum, 2010, s. 1-40.

LINDSTRȮM, K. - KULL, K. - PALANG, H.: Landscape Semiotics: Contribution to Culture Theory. In: LANG, V. - KULL, K. (eds.): Estonian Approaches to Culture Theory. Approaches to Culture Theory, 4. Tartu: University of Tartu Press, 2014, S. $110-132$. 
MENTGES, G.: Für eine Kulturanthropologie des Textilen. Einige Überlegungen. In: MENTGES, G. (Hrsg., unter Mitarbeit von Nina Schack und Heike Jenß): Kulturanthropologie des Textilen. Sonderband. Textil - Körper - Mode. Dortmunder Reihe zu kulturanthropologischen Studien des Textils. Berlin: Ebersbach \& Simon, 2005, S. 11-54.

MØHL, P.: Village Voices: Coexistence and Communication in a Rural Community in Central France. Copenhagen: Museum Tusculanum Press, 1997.

NÖTH, W.: Ecosemiotics and the Semiotics of Nature. In: Sign Systems Studies, 29, 1, 2001, s. 71-82.

SALAŠOVÁ, A.: Vizuálne hodnotenie krajiny v kontexte ochrany krajinného rázu. Životné prostredie, 3, 2020, s. 131-141.

WEISS, S.: „Orte und Nicht-Orte“. Kulturanthropologische Anmerkungen zu Marc Augé. Mainzer kleine Schriften zur Volkskultur, 14. Mainz: Gesellschaft für Volkskunde in Rheinland-Pfalz e.V., 2005.

\section{About the author}

\section{Martin Henzelmann}

University of Greifswald, Faculty of Arts and Humanities, Department of Slavonic Studies, Greifswald, Germany martin.henzelmann@uni-greifswald.de 
